Österreichische Akademie der Wissenschaften / Austrian Academy of Sciences AAS WORKING PAPERS IN SOCIAL ANTHROPOLOGY Volume 33

\title{
Dawn Chatty \\ A POST-IMPERIAL LENS ON DISPLACEMENT AND REFUGE IN THE MIDDLE EAST
}
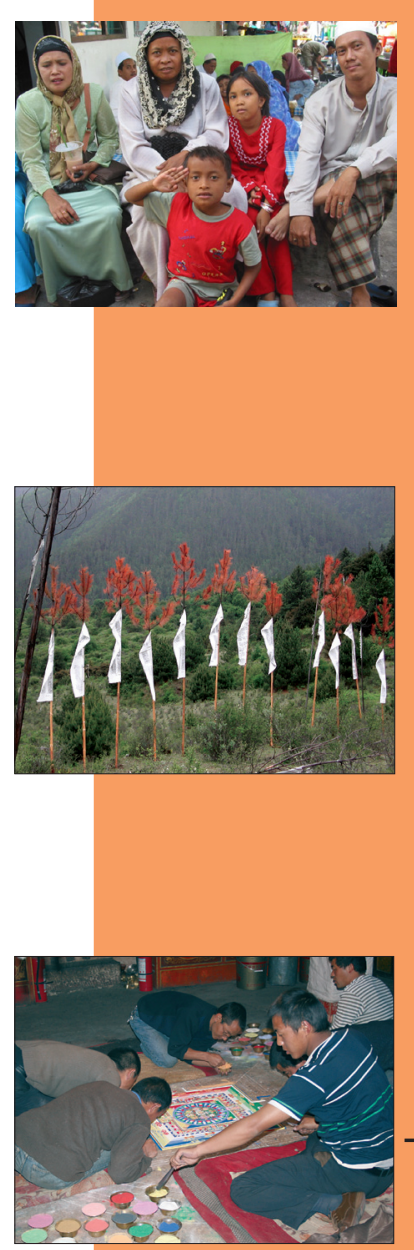

Band 33 


\section{AAS Working Papers in Social Anthropology / \\ ÖAW Arbeitspapiere zur Sozialanthropologie}

ISBN-Online: 978-3-7001-8392-1

DOI: $10.1553 /$ wpsa33

Wien 2018

Editors / Herausgeber:

Andre Gingrich \& Guntram Hazod

(C) Institut für Sozialanthropologie

Österreichische Akademie der Wissenschaften

Hollandstraße 11-13

A-1020 Wien

Fax: 01/ 51581-6450

E-Mail: sozialanthropologie@oeaw.ac.at 


\title{
A POST-IMPERIAL LENS ON DISPLACEMENT AND REFUGE IN THE MIDDLE EAST*
}

\author{
Dawn ChatTy
}

\begin{abstract}
:
This paper will address how today's refugee regime and response to displacement in Middle East might have roots and precedents, but also ruptures with its Ottoman past. Imperial encounters with multiculturalism and ethnic diversity characterised the Ottoman and Austro-Hungarian Empires as well as the colonies that were ruled by European empires. Of all these colonial and imperial encounters, perhaps the Ottoman Empire was uniquely challenged to consider and implement systems of resettlement and reterritorialisation in ordered to address, organise, and manage the mass influx of peoples from its border regions into the heartland of its southern provinces. An understanding of this post-imperial experience might be useful to disentangle contemporary state attitudes and linkages to displacement dynamics and pave a way to better practices.
\end{abstract}

This study emerges from a simple observation. In the course of several decades of living and researching in Damascus, I was regularly struck by the nature of the city's cultural and social makeup. It was home to many social groups: Muslim refugees from Crete, Albanian, Uzbek, Armenian, Circassian and Kurdish forced migrants, and of course Palestinian refugees. Certain quarters of the city carried these legacies in their names: Harat al Akrad (Kurdish Quarter): Muhajiriin (site of the first purpose built housing for refugees from Crete); and, Arnaout (Albanian Quarter). Some of these areas were populated by individuals returning from the Muslim Pilgrimage, the Haj, but by and large, these were communities of forced migrants. They were not ghettos, but thriving fully integrated quarters of the city. How, I wondered, had it been possible for these communities to be socially integrated, and yet non-assimilated for some decades in a country where the discourse on socialism and homogeneity of its citizens prevailed? The answer I felt lay in understanding the history of their forced migration and reception in the host country - the Ottoman Empire. Focussing on one particular meta-ethnic group, the Circassians, I explore the humanitarian response to their movement both nationally and locally. The Circassians are one of many groups that were on the move at the end of the 19th century having been pushed from their Ottoman homeland in the contested borderland shared with Tsarist Russia. Their reception and eventual integration in the region provides important lessons for the contemporary refugee regime.

We came in carts - big carts - eating and drinking were all done in the carts - all the way from Abkhasia to Sham [ Syria ] ... My mother was born in Turkey in 1870 at the time of the war against Russia. She was carried here in the saddlebags of our grandfather's horse. They came to Jaulan and settled in one of the 12 Circassian villages. Ours was the closest to Qunaytrah. Our house was the biggest, our villages were the best. ... All the houses had red tiles for roofs. We lived with my parents and grandparents. We had oil lamps and we used wood for heating. We had forests and we used to bring the wood from there for burning for heating. Until 1947 we had no electricity. We had an Arab school and a Circassian school, but

* The present contribution is the written version of a keynote presentation held by the author in the framework of the Institute for Social Anthropology's spring retreat, May 15, 2018. 
that was closed down in 1936. Some families, mainly who supported the Circassian school, wanted to return to Circassia, but others wanted to remain. We learned Arabic in school and we spoke Circassian at home. When I finished school, I worked on the land for four years and then joined the army. It was the time of the French Mandate. Sometime around my 25 or 26 birthday I got married. For Sharkass [Circassians], marriage is arranged between the couple. I got married during WWII; it was when Paris fell in June 1940. My wedding was in total darkness. It was forbidden to have any lights at night. We had children between 1940-1958. My last child was born on September 5, 1958. He is in Russia now (Abdul-Salam Damascus, 2005).

\section{Overview / background}

In our contemporary era the Nanson passport of the 1920s is often referred to as the beginning of modern refugee regime. This article argues that the origins of our contemporary refugee regime is not post WWI but rather the middle and late 19th century late Ottoman Empire, a period when forced migration and dispossession of millions from the borderlands with Imperial Russia pushed the Ottomans to respond with a special legislation, followed by government commissions and directorates to provide first asylum and then space for resettlement.

To understand the post imperial lens on displacement and refuge, we need to start with some definitions: who is a displaced person, who is a refugee, and who is an asylum seeker. At the close of WWII when the level of carnage came to be assessed, the world's peace makers - the founders of the United Nations, decreed that never again would such death and destruction prevail. And a set of legal definitions were agreed to identify the 'refugee' and to organise aid to those deserving of international assistance. But in the contemporary refugee aid regime definitions of who is deserving of assistance matters a great deal.

The question I would like to explore is whether the contemporary refugee aid regime is an outgrowth of the imperial and colonial past or largely an abrupt disjuncture from the past. Of all these colonial and imperial encounters with displaced peoples, the Ottoman was uniquely challenged to consider and implement systems of refuge, resettlement and reterritorialisation in order to address, organise and manage the mass influx of peoples from its border regions into the heartland of its southern provinces.

After addressing contemporary definitions and contemporary systems of humanitarian aid and refuge, this paper will look back at the Ottoman legacy and consider how today's system of addressing forced migration and displacement in the Middle East might still have roots and precedents, but also ruptures with its Ottoman past. This imperial legacy is important to help disentangle post-colonial state attitudes as well as reveal potential for change and improvement in refugee aid delivery in the future.

All people in all societies create descriptive frames, categories and typologies to organise our understanding of ourselves and others. It is a way of managing our surroundings and setting us apart from others. In our contemporary era of the nation-states, belonging to a state is the norm and non-state membership - being without a state - is considered irregular and dangerous. State bureaucracies seek to regularise the status of all its subjects with labels and paperwork. All nationals of a state are granted papers, generally from birth, which identify them and allow them some freedom of movement within the state. Others regularise their association with the state, 
by persuading that state that there is much to be gained by admitting them either because of their skill sets, or their wealth, or in some cases by winning a lottery [US immigration]. Some make a decision, without duress, to move from one country to another and others find, that having lost the protection of their state of origin, must flee - often involuntarily to find safety in another state. The distinction between the forced migrant and the voluntary migrant is one which is debated in in academia, where labels come to have particular meanings and rights. Anthropological notions of the self and the other come into play here as does Agamben's notion of the 'homo sacer' who is outside the bounds of the nation state - beyond its laws but also in a state of 'bare life' (1998).

Post WWII two definitions of 'refugee' emerged: one is a legal definition, and the other is an operational one. The legal definition is set out in the 1951 Convention on the Status of Refugees and defines the refugee a person who "owing to a well-founded fear of being persecuted for reasons of race, religion, nationality, membership of a particular social group, or political opinion, is outside the country of his nationality, and is unable to or, owing to such fear, is unwilling to avail himself of the protection of that country" (UNHCR 1951). The other, earlier definition is an operational definition created to address the international concern for the forced migration of nearly threequarter of a million Palestinians from their homes during the 1947-48 War in Palestine. When the United Nations created a special agency to deal specifically with Palestinians - the United Nations Relief and Works Agency (UNRWA), its working definite of a Palestine refugee was any person whose "normal place of residence was Palestine during the period 1 June 1946 to 15 May 1948 and who lost both home and means of livelihood as a result of the 1948 conflict (UNRWA 1979)." As we use the term, 'refugee' is not a label for a special, generalisable; 'kind' or 'type' of person, but rather it is a descriptive rubric that includes within it a world of socio-economic statuses, personal histories, and psychological situation.

\section{The contemporary refugee regime}

Common understandings of our modern refugee regime start with WWI. Over these 100 years - between 1914 to 2018 - one can talk about five phases. The first phase between 1914-1939 saw the emergence of a regime to care of the displaced by WWI mandated by the League of Nations. At this time position of High Commissioner for Refugees was created and the issuing of special travel document for stateless peoples was initiated. Phase two was entered into Post WWII when more than 40 million European refugees were wandering around Europe. The United Nations set up the United Nations Relief and Rehabilitation Administration (UNRRA) to provide aid and to help return over 7 million refugees to their countries of original. Phase three between the 1960s and the 1980s was a confused and contested era with both migration stemming from the Cold War and Post-Colonial migration capturing the public imagination. As the Colonial era ended and the United States pulled out of Vietnam, large numbers of non-European refugees were kept in the Global South, while in the north many refugees from behind the Iron Curtain were largely welcomed and seen as heroic escapees from Communism. Phase four, the 1990s, saw the end of the Cold War and the emergence of new kinds of wars and complex emergencies. The type of refugee changed; no longer perceived as a heroic flight from communism alone. The new wars were sometimes small wars and resulted in fragile or failed states, such as Somalia. The last phase - late 1990 s into the 21st century, and one in which we are in currently, is of a fortress mentality. There is a blurring of the divide between those fleeing political persecution and those fleeing poverty. It is a period when asylum and migration as concepts are obscured or wilfully made fuzzy; where 
managing refugees from afar is preferred to dealing with people in need close up. It is an era where the mass influxes of people fleeing civil war and armed conflict with non-state actors are regarded as migrants - especially as they try to reach European shores by boat.

Phase 1: The Fridtjof Nansen era

At the end of the Paris Peace Conference in 1919, the Allied Powers at the urging of the American President Woodrow Wilson decided to create a League of Nations to manage and regulate relations between nations. Fridtjof Nansen, a Norwegian explorer, scientist, diplomat and humanitarian was tapped to serve as the league's first High Commissioner for Refugees. Nansen served from 19201930, helping hundreds of thousands of refugees to return home. His efforts enabled many others to become legal residents and find work in the countries where they had found refuge. Nansen saw that one of the biggest problems facing refugees was the lack of internationally recognised identification papers. His solution, which came to be known as the 'Nansen passport', was the first legal instrument for the international protection of refugees.

Within a year of taking office he was faced with a major crisis when Lenin stripped all 'white Russians' in Europe at the time of their citizenship. Nansen recognised that people needed to be able to travel to move to find work to support themselves and their families. He initiated the travel document which has taken on his name, the 'Nansen passport', and issued nearly 500,000 travel documents mainly to the stateless Russians, but later also to Armenians from Turkey, and Assyrian Christians from Iraq . His efforts enabled many others to become legal residents and find work in the countries where they had found refuge.

When famine broke out in Russia in 1921-1922, Nansen organised a relief programme for millions of its victims. He clearly established a system of rapid relief in emergency followed by the issuing of travel documents so that forced migrants could become self-sufficient whenever possible supporting themselves and their families where they found work.

Phase 2: Post World WWII - the right to have rights

By end of WWII there were more than 40 million European refugees. The United Nations set up its Relief and Rehabilitation Administration (UNRRA) to provide aid to them. This included returning over seven million refugees, then commonly referred to as displaced persons or DPs, to their country of origin and setting up Displaced Persons camps throughout Europe for the one million refugees who refused to be repatriated.

Near simultaneously, the United Nations asked Eleanor Roosevelt, the widow of the American president, to chair a committee to draft a Universal Bill of Rights, an international document that states the basic rights and fundamental freedoms to which all human beings are entitled. The drafting committee included international figures such as Charles Malik (Lebanon) William Hodgson (Australia), Hernan Santa Cruz (Chile), Peng Chun Chang (China), and Rene Cassin (France and Charles Dukes (UK). The committee decided to keep the document as a statement of fundamental principles rather than a treaty and to that end they hoped the Declaration would have a profound impact on how nation states developed their domestic laws.

The two most important articles of the Universal Declaration of Human Rights for our purposes here are:

Article 13

(1) Everyone has the right to freedom of movement and residence within the borders of each state. 
(2) Everyone has the right to leave any country, including his own, and to return to his country. $\underline{\text { Article } 14}$

(1) Everyone has the right to seek and to enjoy in other countries asylum from persecution.

(2) This right may not be invoked in the case of prosecutions genuinely arising from nonpolitical crimes or from acts contrary to the purposes and principles of the United Nations.

In 1948, as the aftermath of the 1947-48 War in Palestine left more than 750,000 Palestinians displaced, dispossessed and unable to return to their homes, the United Nations created the UN Relief and Works Agency (UNRWA) to support refugees from Palestine who were caught in a liminal state willing but unable to exercise their right to return to their homes after the war in Palestine had ceased. Then in 1951, the United Nations set out the Convention on the Status of Refugees and created the 'temporary' agency to oversee the repatriation, or resettlement of largely refugees from Europe in the wake of WWII. It was anticipated that the UNHCR would only remain active for a few years, and once all of Europe's refugees were resettled or returned to their places of origin, the agency would be shut down. Under the terms of the 1951 convention, 'refugees' became separated form economic migrants, a status protected now by international law.

Phase 3: Cold War and post-colonial era 1960s-1980s

As the Colonial era ended and the United States pulled out of Vietnam, the UNHCR suddenly had to deal with a large number of non-European refugees. However as the UNHCR 1951 Convention was limited to persons who became refugees as a result of events in Europe occurring before 1 January 1951, the 1967 Protocol came into effect lifting the geographical and temporal restrictions for the 1951 Convention. During this Phase, some refugees - those fleeing from behind the Iron Curtain were largely welcomed in Western Europe and seen as heroic escapees from Communism. In other parts of the world, however, the flow of forced migrants were not as well received and we began to witness some countries turning away people displaced and dispossessed by war and armed conflict such as in south east Asia. In Africa millions of people were also on the move as the new nations began to recalibrate their frontiers.

Phase 4: New wars, many hued refugees 1990s

With the end of the Cold War and the collapse of the Soviet Union, a new type of conflict emerged. In some cases it was the fracturing of states that had been held together under the Soviet System. Yugoslavia, for example, broke up and in its place were six new states: Bosnia-Herzegovina, Croatia, Macedonia, Montenegro, Serbia, and Slovenia. The carving out of new borders between these new states and ancient kingdoms resulted in significant but often confused armed conflict in the Balkans with civilians taking refuge in ethnic enclaves and in neighbouring states. Some labelled this period as one of small wars; but proxy wars often conducted by the large powers in fragile or failed states such as Somalia (Duffield 2001; Kaldor 2012).

The war in Bosnia-Herzegovina in the 1990s and its incendiary extension to much of the Balkans is one example of the way in which those fleeing fighting, non-state armed actors, and rumoured sectarian and ethnic cleansing resulted in a many 'hued' refugee. Some were fleeing the actual conflict and others from fear emerging from the rumours and the conspiracies which abounded. Claiming asylum in Europe was possible and numerous Muslim and Christian Bosnians found temporary protection in German and in the UK among other places. But it was beginning to become increasingly difficult for these citizens of the Balkan states to find sanctuary in Europe. 
Mass influx made politicians in Europe nervous even if this flight of civilians was from persistent sniper fire and shelling of civilian market places.

Phase 5: Fortress mentality late 1990s and the 21st century

This is the era we are currently living through where the 'divide' between asylum and migration is being blurred in the media and among politicians and policy makers; where the definition of who is eligible for protection is being 'fudged'; and where the claims of those seeking international protection is increasingly being scrutinised and questioned. Confusion and distortions now abound in the imprecise distinctions between who is an economic migrants and who is a 'bona fide' refugees.

The antipathy in the media and among some social groups for those seeking refuge from persecution in their countries of origin is increasingly being articulated as a rise in 'bogus asylum seekers'. These distortions and confusions in the labelling of those who are economic migrants and those who are seeking asylum from persecution and armed conflict is accompanied by a growing 'fortress' mentality. Many populist politicians are arguing that we need to 'keep them out' failing to acknowledge that refugees, once integrated, into their countries of asylum make significant contributions to the economy. Instead we see a rise in discourses of security where victims of armed conflict and oppression are viewed as security risks. Border patrols and open sea operations are mounted not so much to save people but to push them back. And bilateral treaties are entered into to contain migrants and asylum seekers away from European borders along the eastern and southern Mediterranean Rim.

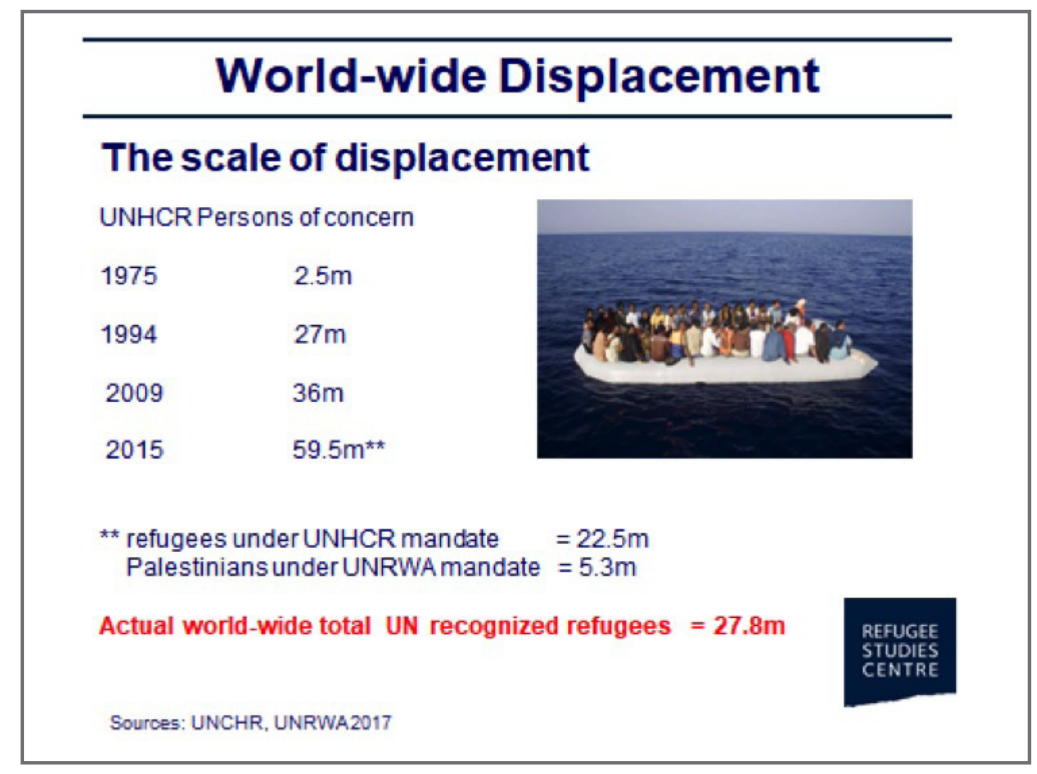

World-wide displacement

On a global scale, the people of concern to the United Nations Agency for Refugees has grown astonishingly fast. In 1975 the UNHCR's people of concern - all persons whose protection and assistance is of interest to UNHCR - there were 2.5 million. In 2015 the numbers had grown to 59.5 million. These figures include 22.5 million recognised refugees under the UNHCR mandate, and 5.3 million Palestinians under UNRWA mandate (UNHCR 2015; UNRWA 2017). ${ }^{1}$ UNHCR's authority to act on behalf of 'persons of concern' other than refugees is based on UN General Assembly resolutions. Its mandate includes a responsibility to act on behalf of 'returnees' - refugees

\footnotetext{
${ }^{1}$ Actual world total UN recognised refugees are 27.8 million.
} 
who chose to voluntarily return to their country of origin , stateless persons, and in some situations, internally displaced persons.

Middle East's heavy burden

The United Nations estimates that nearly $26 \%$ of the world's refugees are hosted in the Middle East and North Africa. Its current figures suggest that the total in the region is 5.8 million. However when one adds the 5.3 million Palestinian refugees in the Middle East to that global figure, then the total percentage of refugees in the Middle East represents $40 \%$ of the world's refugees.

The current humanitarian crisis emerging from the Syrian uprising and civil war has seen Turkey with a population of 74 million take in close to 4 million displaced Syrians, while Lebanon with a population of 4.5 million has taken in at last count in 20151.1 million (33\%), and Jordan with a population of 6.7 million has taken in over 600,000 (10\%). By comparison Germany with a population of 79 million has accepted more than 800,000 displaced Syrians, while the United Kingdom with a population of 64 million has agreed to accept up to 20,000 by the year 2020 (UNHCR 2018).

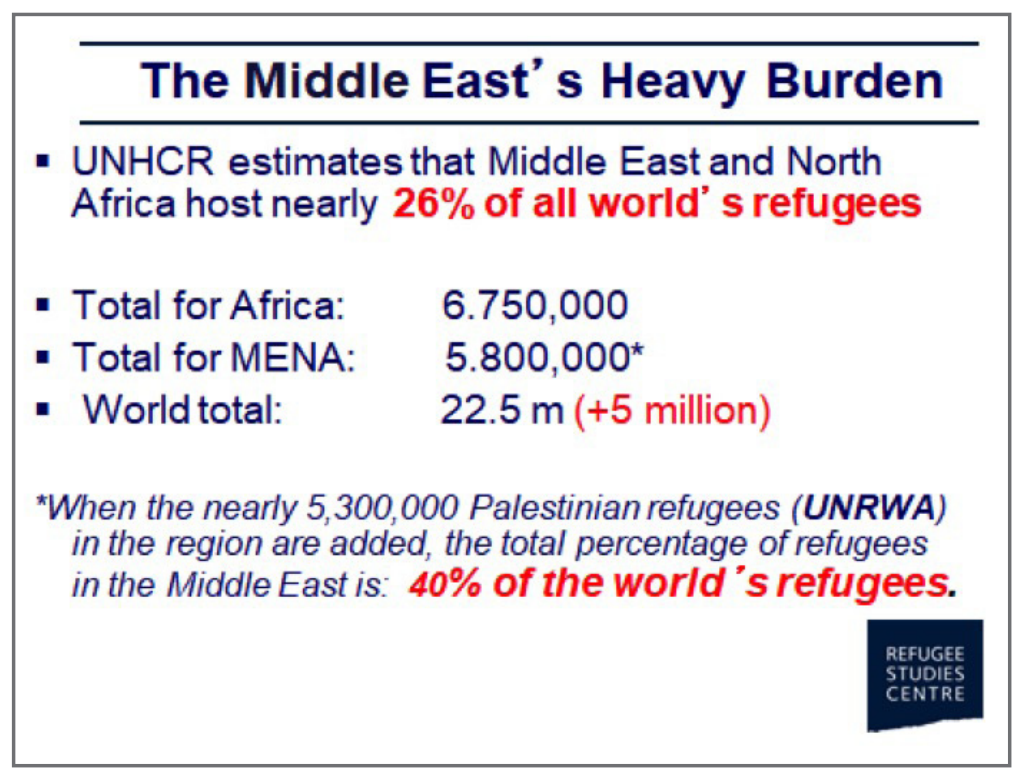

\section{9th and 20th-century displacement in the Middle East}

The 19th and early 20th centuries marked the beginnings of modern, large-scale, involuntary movements of people across the Eurasian continent. Russia and the Ottoman Empire fought six wars during that period, each war resulting in territorial losses for the Ottomans. In addition, the European, Russian, and Ottoman Empires faced pressures to transform themselves into nationstates. The first of these modern 'nation-states' to be carved out of the Ottoman Empire was Greece in 1832, which became a client state of Russia and Great Britain. Greece then steadily encroached on Ottoman territory and each of these gains precipitated the flight of part of the local Muslim population. ${ }^{2}$ The latter part of the 19th century saw the establishment of Bulgaria, Serbia and Montenegro in the heartland of the European part of the Ottoman Empire. Each new state sought to 'unmix' their nationalities as their minorities came to be regarded as obstacles to state-building. ${ }^{3}$

\footnotetext{
${ }^{2}$ Greece acquired from the Ottoman empire Thessaly in 1881, Crete in 1908, and Macedonia in 1913.

${ }^{3}$ The term 'unmixing of peoples' was attributed to Lord Curzon in his reflections on the Balkans Wars.
} 
As the three great empires of Europe and the Middle East fell, the movement of people into and within the Middle East far surpassed that of those fleeing the region. The history of Ottoman tolerance for minorities as expressed in the system of millets (legally protected religious minority groups) is part of the explanation for this great inflow. Social groups in the Ottoman Empire were very much based on ethno-religious ties to the millet, perhaps more so than place of birth. Those who belonged to the Muslim millet included: Arab, Kurds, Albanian, Turks, and Kosovars. The Christian millet included: Arabs, Greeks, Armenians, Serbians, and Bulgarians. And the Jewish millet included: Arab (Mizrahi), Sephardic, and Ashkenazi. Belonging was based not on physical birthplace alone, but specifically included social community/ ethno religious community or 'millet'. These social communities with their own religious hierarchies were dispersed throughout the empire, meaning that movement and mobility within the social construction of the millet was an important feature of feature social life at the time. Armenians, for example, were found in Constantinople, in Aleppo, Damascus, Jerusalem and Cairo and supported their fellow coreligionist throughout the empire.

Although there had been significant movement of Muslim people fleeing Greece after the declaration of that kingdom in 1832, it was the aftermath of Crimean War of 1853-57 that saw the mass influx of forced migrants into the Ottoman Empire. Over a period of several years the Ottoman Sublime Porte in Constantinople had to deal with waves of forced migrants totally nearly 3 million in the space of 5 years. One outcome of the Crimean War, which the Ottomans and their allies the British and the French, technically won, was the settlement at the Treaty of Paris in 1856 which saw 500,000 Muslim Tatars removed from the Crimea and resettled in the European Ottoman Empire along with the voluntary flight of 500,000 Cossacks (Georgians and Ukrainians). These Tatars were given several months to sell up and move out of the Crimea which - now bordering on Russia was to be cleaned of its Muslim population. On the other side of the Black Sea, another wave of Muslim dispossession came from the Caucasus. These were Circassians and Abazas who were unhappy with the outcome of earlier Russo-Ottoman Wars, but who had stayed on their lands and resisted the continuing Russian campaigns to occupy their homelands. These groups were finally defeated in 1865, a few years after the Russians captured their leader Sheikh Shamil in 1859.

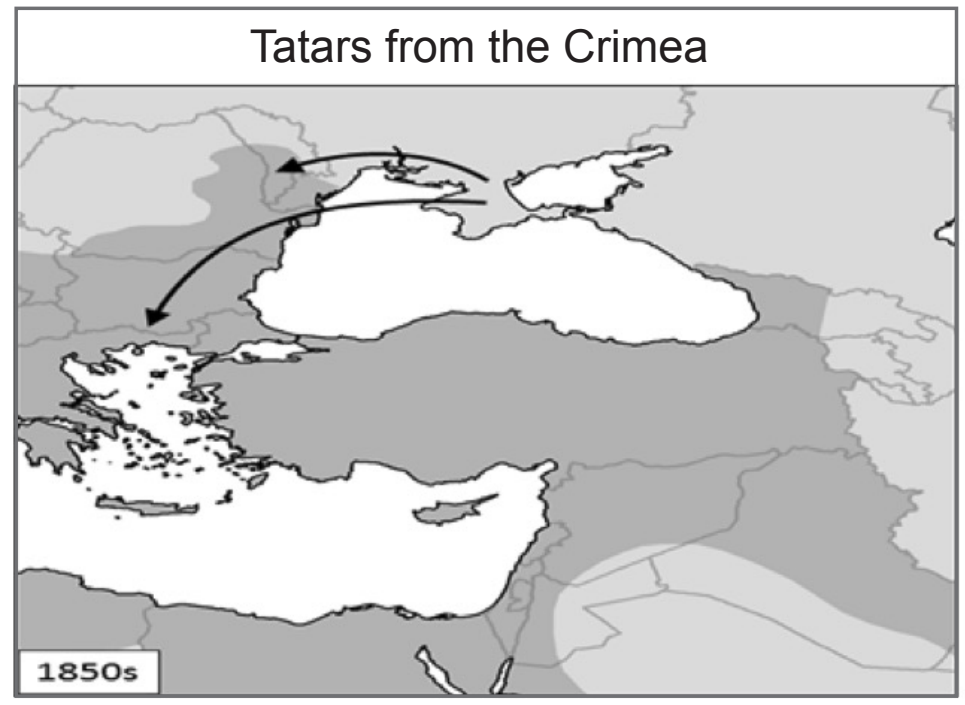
as 520,000 Muslims were forcibly moved out of Russia and into the Ottoman Empire. Over the next twenty years another 2 million forced migrants moved from the borderlands with Russia into the 


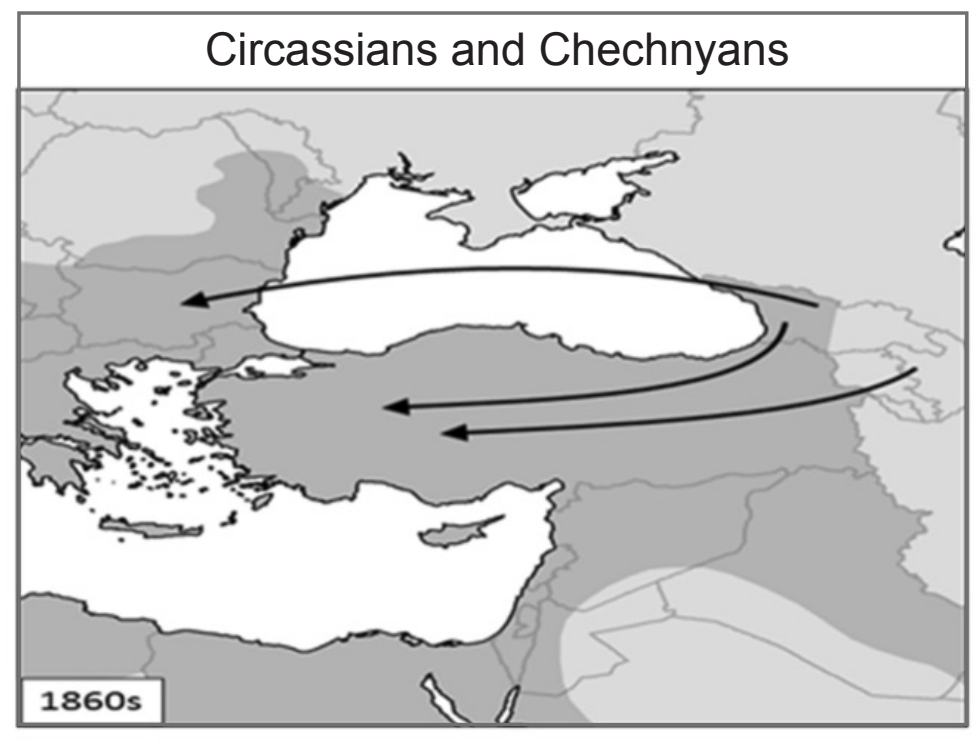

Ottoman Empire. These forced migrations of Muslim groups from the Caucasus regions continued throughout the 1880 s and 1890 s and into the first two decades of the 20th century. This last wave of forced migrants in the 20th century was estimated at another 500,000 people (Karpat 1985).

\section{Refugee code of 1857: Ottoman response to mass influx}

The mass influx of millions of forced migrants into the empire was a cause of concern to the Ottoman Sublime Porte. In the aftermath of the Crimean War (1853-57) the Ottoman authorities instituted the Refugee Code of 1857 (also referred to in some texts as the Immigration Law) whereby 'immigrant' families and groups with only a minimum amount of capital were given plots of state land with exemptions from taxes and conscription obligations for 6 years if they settled in the European Ottoman Empire ( Rumeli) and for 12 years if they settled in Anatolia or its southern provinces in Bilad al-Sham ( Greater Syria). The ethos clearly evident was help move people out of the emergency phase of crisis and assists them to become self-sufficient. Thus these forced migrants had to agree to cultivate the land they were given and not to sell it for 20 years. They were in return promised freedom of religion, whatever their faith, and were permitted to construct their own places of worship. News of this decree spread widely both along the frontier zone and in Europe. Requests for farm land came from individuals in Hungary, Bohemia, Poland, Switzerland, Italy and even the US. In order to process the rising requests under this Code, a Refugee Commission was set up in1860 under the Ministry of Trade (Shaw and Shaw 1977, 115).

The Ottoman response initially was not how do we stop these numbers, but how do we integrate and resettle them in the most beneficial places for the Empire. Thus the terms for resettlement in the underpopulated southern provinces of the empire were twice as enticing as those for resettlement in Rumeli, the European part of the Ottoman Empire. Repopulating and reinvigorating tax farming was a primary concern for the Ottoman authorities but also dispute settlement was also important and often achieved by settling the Circassian forced migrants in areas between local communities were in constant friction. Over time the social and political economy of the Ottoman Empire changed and the resettlement areas also changed. But though the Ottoman state took a decentralised approach to dealing with these huge numbers of dispossessed. Dispersal was completed as quickly as possible to provincial cities and migrants were integrated as subjects of the state.

Throughout the 19th century the Ottoman state received exiles and political refugees from neighbouring countries, which caused political tensions when the Ottomans refused to return the refugees to the authorities of their countries of origin. The best known example of this first modern example of non-extradition was at the close of 1848-49 Hungarian Uprising when Louis Kossuth 
and his Hungarian and Polish compatriots asked for asylum in the Ottoman Empire after their in Transylvania by the Habsburg and Tsarist troops. They fled to Wallachia and Moldavia (provinces of the European Ottoman Empire later renamed Romania). They numbered 16,000 including 11,000 troops. The Ottomans granted them sanctuary, but divided them into groups and moved them away from border noting that since these soldiers have taken refuge with the Sultan, their extradition and surrender to the Habsburgs would not accord with established Ottoman traditions. These sentiments were attributed to Ahmed Cevdet Pasha and enhanced the Ottoman state's reputation among the 'Comity of Nations' (France and Great Britain, in particular).

The immigration as well as refugee policy of the Ottoman Empire evolved over the 19th century but basically remained fairly liberal, generous and open. Economically it was used to resettle under-populated agricultural areas to create tax farming surpluses. Politically it was used to defend frontiers and to revive the military strength of the army by encouraging forced migrant and exiled Circassian, Polish and Hungarian military officers to join and keep their previous rank. And environmentally these newcomers were used to help drain swamps and turn malarial areas into productive zones for tax farming (Gratien 2017). It was as Karpat emphasised probably the first instance of direct, prolonged and rational state social planning in the Muslim world and probably the first of its kind in the world to regulate immigration and devise a settlement policy(1974).

By the time the Ottomans' fought their last war with Russia 1877-78, the Refugee (Immigration) Commission had been renamed as Commission for the General Administration for Refugee (Immigration) Affairs. The General Administration was responsible for hosting all immigrants when they reached Ottoman soil. It was responsible for locating lands for resettlement and development of under populated areas; for transporting the refugees and immigrants to these lands, and if necessary giving these immigrants, housing, seeds to plant, and animals to herd. In some cases, winter heating supplies, and monthly stipends were also handed out for those not yet able to harvest. Local donations were encouraged. Ottoman used the Muslim principle of aiding migrants by charging the host communities to accept the immigrants as brothers. In one case, the Wali (governor) of Damascus found in 1878 that he had to levy a tax of four piasters (in today's terms about £25) per head on the registered male population in order to provide emergency food and clothing to the forced migrant Circassians arriving in the city (Lewis 1987).

\section{End of empire: precedents and ruptures}

The late Ottoman Empire's refugee and immigration policies provided its forced migrants with just enough emergency support to stave off starvation and poverty on first arrival. Moving out of the emergency phase of each of these crises, it also provided its immigrants and refugees with just enough support - through registered farm land, seeds, and other mechanism of support. But much of the planning and strategy for survival after that was left to the group and community itself. The tools for self-sufficiency were made available, but the community - Circassian, Chechnyans, Albanians, and others had to emerge as active agents in their own destiny, not passive victims or dependents on the state. These forced migrants in the Middle East, with no option to return and little chance of onward migration converted themselves into successful ethnic minorities communities; they found a way to physically and socially integrate in their new surroundings, but at the same time resisted the phenomenon of assimilation over the long-term.

With the close of WWI the Ottoman Empire was defeated and much of its southern territory 
given to France and Britain under a system of mandated states to be brought to full independence when state institutions had been established and were understood to be able to bear the burden of full independence. The severely truncated remains of the Ottoman Empire were subjected to an invasion from Greece which resulted in massacres of Muslim villages. Kemal Ataturk, who watched Greece's military progress inland decided he had to act. After a three year 'War of Independence' Kemal Ataturk emerges as the head of the new Turkish Republic which encompassed the entire Anatolian Plateau as well as Constantinople (soon to be renamed Istanbul). Despite Ataturk's push to modernise this new state, the successor of the Ottoman Empire, the early years of the Turkish Republic saw the protection of refugees still based on certain principles inherited from the Ottoman Empire especially in terms of resettlement policies (Hirschon 2003; Loizos 1999). But the new state was not keen on employing Ottoman institution. Instead it searched for European-style institutions, constrictions and civil law (Devereux 1963). ${ }^{4}$ This meant the rejection of imperial administrative institutions with nothing to replace them with regards especially to the forced migrants and other dispossessed peoples at the close of WWI. During this period of upheaval, dispossession, and turmoil, many of the international agencies that had worked with the Ottoman Administration for refugees and immigrants continued to function. This was especially so for many of the church based charities which were based in the US and the UK (Watenpaugh 2015).

\section{Coming full circle? Imperial precedents and ruptures}

It was, simultaneously, the Russian famine and statelessness crisis in Europe that led the League of Nations to appointed its first Refugee High Commissioner. Fridtjof Nansen was confronted with these two crises as he took office. First, he found he had to provide and organise the provision of emergency relief to Russia to prevent massive starvation. This, he adeptly orchestrated with significant help from the US and the UK. Both countries had been providing significant relief to people in the Ottoman Empire, especially children and orphans. Nansen was able to persuade both countries to continue their support with the same groups, despite the collapse of the empire. Having dealt successfully with this effort he was then confronted with over 500,000 white Russians in Europe who had been stripped of their citizenship by Lenin in 1921. Again, following precedent established during the late Ottoman period, he recognised that he needed to find ways of helping the stateless Russians (and later Armenians and Assyrians) become mobile. They needed to be able to travel to find work to support themselves and their families. Nansen was able to transform his 'passports', officially identification paper, into internationally recognised travel documents permitting individuals to come and go in search of work. He recognised that these stateless individuals needed to be able to return to the country which issued them with their travel documents. His solution, which came to be known as the 'Nansen passport' was the first modern legal instrument for the international protection of refugees. The 'Nanson Passport' was issued to more than 500,000 refugees, in some ways continuing the freedom of movement which had been inherent in empire, but not necessarily between nation-states.

The Ottoman state saw the necessity of moving form emergency phase of a crisis to a resettlement or development phase rapidly. There were no protracted liminal 'refugee or immigrant settlements in the Ottoman Empire. State assistance shifted rapidly to helping the refugees and new immigrants to become self-supporting subjects (and later citizens) of the state. The state clearly saw the

${ }^{4}$ During the Tanzimaat reform period of the Ottoman Empire, a constitution and a parliament had been agreed and in 1876, putting it among the earliest members of the 'Comity of Nations to do so'. 
economic potential of the refugee and immigrant to revive tax farming as the new comers became self-sufficient. The state also saw that technological advances in draining swampland could be used as a key to successful resettlement of underpopulated or seasonally populated areas associated with malarial. Dispersal throughout the empire was also considered important to preserve the multi-cultural character of the state so that there were no colonies or ghettos. Each newcomer social group was encouraged to remain different. Together with the widespread acceptance of 'otherness' in the southern provinces of the empire and a tolerance for socio-religious institutions that reflected vestigially on the millets of the Ottoman Empire, a form of local cosmopolitanism emerged which enhanced these immigrant and refugee groups.

What of the ruptures from Ottoman policies? The liberal and open policy towards forced migrants and immigrants in the empire has been replaced by a fortress mentality throughout Europe. The refugee is not seen as a potential citizen of the state, but rather as a security threat and potential extremist. The economic and political benefits which immigrants and refugees were able to contribute to the empire have only occasionally been recognised in the west. Today it is largely in think tank documents and economic studies that the contribution of the refugee and immigrant is acknowledged. But this is not reflected in the media nor in the nationalist and populist politics. And finally the social and religious obligation to assist the needy which was so clearly foundational to much of the support which refugees received by the Ottoman state as well as in the provincial hosting communities is greatly undervalued today in the west. All societies everywhere in the world have mechanisms which implement a 'moral economy' of generosity to the needy and the recognition that there will be a return 'presentation' by the needy when they find themselves in better circumstances (Mauss 2016 [1925]). In the Ottoman Empire these institutions had strong social and religious foundations. In our contemporary society they exist, as well, and expressions of solidarity and mutuality are growing at the local level in all the states of Europe. Only our state level politics has not heard the messages now rising from below. Unless they start listening, the future for forced migrants in the west looks stark indeed.

Dawn Chatтy is Emeritus Professor in Anthropology and Forced Migration and former Director of the Refugee Studies Centre, University of Oxford, United Kingdom. Her research interests include refugee youth in protracted refugee crises, conservation and development, pastoral society and forced settlement. She is the author of Displacement and Dispossession in the Modern Middle East (2010), From Camel to Truck (2013), and Syria: The Making and Unmaking of a Refuge State (2018). 


\section{Literature}

Agamben, Giorgio. 1998. Homo Sacer: Souverign power and bare life. D. Herrer-Roazen, transl. Stanford: Stanford University Press.

Devereux, Robert. 1963. The First Ottoman Constitutional Period. New York and London: Oxford University Press and Johns Hopkins Press.

Duffield, Mark. 2001. Global Governance and the New Wars: The Merging of Development and Security. London Zed Books.

Gratien, Chris. 2017. The Ottoman Quagmire: Malaria, Swamps, and Settlement in the Late Ottoman Mediterranean. Internatinal Journal of Middle Eastern Studies 48(4): 583-604.

Hirschon, Renée (ed.). 2003. Crossing the Aegean: An appraisal of the 1923 compulsory population exchange between Greece and Turkey. Oxford: Berghahn.

Kaldor, Mary. 2012. New and Old Wars: Organized Violence in a Global Era. London: Polity Press.

Karpat, Kemal H. 1974. Ottoman immigration policies and settlement in Palestine, in: AbuLughod, I. and B. Abu Laban (eds.), Settler regimes in Africa and the Arab world: The illusion of endurance. Wilmette, IL: The Medina University Press International, 57-72.

- 1985. Ottoman population 1830-1914: Demographic and social characteristics. Madison: University of Wisconsin Press.

Lewis, Norman. 1987. Nomads and settlers in Syria and Jordan, 1800-1980. Cambridge: Cambridge University Press.

Loizos, Peter. 1999. Ottoman half-lives: Long term perspectives on particular forced migrations, Journal of Refugee Studies 12(3): 237-263.

Mauss, Marcel. 2016 [1925]. The Gift. Expanded Edition translated by Jane Guyer. Chicago: Hau Books.

Shaw, Stanford J., and Ezel Kural Shaw. 1977. History of the Ottoman Empire and modern Turkey, Vol. 2. Cambridge: Cambridge University Press.

UNHCR. 1951. United Nations Convention on Refugees, Vol. 2008: United Nations High Commissioner for Refugees (UNHCR).

- 2015. UNHCR Regional Response Plan UNHCR.

- 2018. Figures at a Glance. UNHCR.

UNRWA. 1979 UNRWA: Definitions and statistics, June 30, 1979: United Nations Relief and Works Agency for Palestine Refugees in the Near East (UNRWA).

— 2017 UNRWA in Figures, 2016 UNRWA, Communications Division.

Watenpaugh, Keith. 2015. Bread From Stone: The Middle East and the making of modern humanitarianism. Oakland, CA: University of California Press. 